\title{
Global vision of heliconias research as cut flower: a review
}

\author{
Ariadna Linares-Gabriel ${ }^{1}$ (D), Felipe Gallardo-López ${ }^{1^{*}}{ }^{\circledR}$, Magdalena Villarreal ${ }^{2}$ (), \\ Cesáreo Landeros-Sánchez ${ }^{1}$ (i), Gustavo López-Romero ${ }^{1}$ (D) \\ ${ }^{1}$ Colegio de Postgraduados, Campus Veracruz, Veracruz, México, \\ ${ }^{2}$ Centro de Investigaciones y Estudios Superiores en Antropología Social-Occidente, Guadalajara, Jalisco, México.
}

\begin{abstract}
It is relevant to systematize the global knowledge generated about heliconia due to its economic importance in tropical floriculture and the cut flower market. The objective was to explore the results generated in scientific research related to the cultivation of heliconias as cut flower in terms of its methodological approach, research axes, and spatial distribution in terms of the contributions by country. A bibliographic search was conducted in Scopus, Web of science and SciELO based on the keywords "heliconia" and "tropical flowers". Thereafter, a content analysis of the documents was conducted with the Nvivo software using a priori categories in terms of methodological approach, research axes, year, countries, and cultivars or varieties. The results indicate that the scientific contributions are mostly under a quantitative approach (98.1\%). The investigations mainly address productive aspects $(74.5 \%)$, post-harvest aspects $(16.1 \%)$, market $(6.7 \%)$ while industry-used products $(2.5 \%)$ are scarcely addressed. The countries that make the most contributions are: Brazil (54.5\%), Colombia (15.4\%) and Mexico (10.9\%). The most important species are: H. psittacorum, H. bihai, H. spathocircinata, H. rostrata and H. wagneriana. These results suggest conducting research to identify problems from the physiological, environmental, productive, and economic processes, as well as considering the strategies of farmers as a priority. This must be approached from paradigms where social actors (farmers), their development and the impacts of their social tasks on the cultivation of heliconias are considered the main axis.
\end{abstract}

Keywords: Heliconia spp., commercialization, content analysis, production, tropical flowers.

\section{Resumo}

Visão global de pesquisa de helicônias como flor de corte: uma revisão

É relevante sistematizar o conhecimento global gerado sobre heliconia devido à sua importância econômica na floricultura tropical e no mercado de flores cortadas. O objetivo foi explorar os resultados gerados em pesquisas científicas relacionadas ao cultivo de helicônias como flores de corte em termos de abordagem metodológica, eixos de pesquisa e distribuição espacial em termos de contribuições por país. Uma pesquisa bibliográfica foi realizada no Scopus, Web of science e SciELO, com base nas palavras-chave "heliconia" e "flores tropicais". Posteriormente, uma análise de conteúdo dos documentos foi realizada com o software Nvivo, usando categorias a priori em termos de abordagem metodológica, eixos de pesquisa, ano, países e cultivares ou variedades. Os resultados indicam que as contribuições científicas estão principalmente sob uma abordagem quantitativa $(98,1 \%)$. As investigações abordam principalmente aspectos produtivos $(74,5 \%)$, aspectos pós-colheita $(16,1 \%)$, mercado $(6,7 \%)$, enquanto os produtos utilizados pela indústria (2,5\%) são pouco abordados. Os países que mais contribuem são: Brasil (54,5\%), Colômbia (15,4\%) e México (10,9\%). As espécies mais importantes são: H. psittacorum, H. bihai, H. spathocircinata, H. rostrata e H. wagneriana. Esses resultados sugerem a realização de pesquisas para identificar problemas dos processos fisiológicos, ambientais, produtivos e econômicos, além de considerar as estratégias dos agricultores como prioritárias. Isso deve ser abordado a partir de paradigmas em que os atores sociais (agricultores), seu desenvolvimento e os impactos de suas tarefas sociais no cultivo de helicônias são considerados o eixo principal.

Palavras-chave: Heliconia spp., comercialização, análise de conteúdo, produção, flores tropicais.

\footnotetext{
* Corresponding author: felipegl@colpos.mx
} 


\section{Introduction}

In tropical floriculture, species such as orchids (Orchidaceae spp.), anthuriums (Anthurium spp.), heliconias (Heliconia spp.), birds of paradise (Strelitzia spp.), and ginger (Zingiber officinale), are a relatively small segment of the European flower market. These species do not cover the offer and are mainly sold as exclusive (tropical) flowers in mixed bouquets and flower arrangements (Centre for the Promotion of Imports (C.B.I., 2016). In the recent decades, Heliconia was introduced to the flower trade, recognizing itself as an ornamental variety of unusual elegance (Cantor et al., 2014).

The main producing and exporting countries of these flowers are Colombia, Costa Rica, and Brazil. In Africa, the flowers come mainly from Ghana and Zimbabwe. Germany is an important market for tropical flowers but quantitative data on imports and consumption of tropical flowers are not available. Other large tropical flower markets are Italy, the United Kingdom and France. However, at flower auctions in Holland (Royal Flora Holland) and Germany (Veiling Rhein-Maas), a small number of merchants specialize in tropical flowers (C.B.I., 2016).

The possibility of covering the commercial demand throughout the year and the business nature of floricultural production are two important components to participate in the national and international market (Hernández, 2007). Cut flower production is widely adopted in developing countries as a successful economic growth strategy for its ability to generate employment and foreign exchange earnings (Patel-Campillo, 2011). These countries are mainly located in Latin America and Central Africa (Hernández and Avitia-Rodríguez, 2017). Heliconia helps to increase the profits of the cut flower industry worldwide. Inflorescence durability and vivid colors have supported commercialization in the international market (Cantor et al., 2014), causing significant changes in the agricultural base and economic composition of producing regions and municipalities (Patel-Campillo, 2010).

The production and marketing problems in this species are the size and weight of commercial stems, storage requirements and challenges encountered by producers which include aspects of propagation, flowering control, and shelf life in the vase (Pizano, 2005). It is important to emphasize that in addition to these physicobiological and technical problems, there are also economic, social, and political problems. The most notable is that most cut flower producers in developing countries do not benefit from the cooperative system and therefore remain predominantly buyer-driven (Patel-Campillo, 2010). Under this problematic scheme found in the production and marketing of heliconias, further research is required to identify problems from physiological processes (Morais et al., 2015), and on the strategies of the actors and trade regulation which also play a fundamental role in facilitating the reorganization of product chains to compete in world markets (Patel-Campillo, 2011).

The objective was to answer the following questions: What are the main results generated in scientific research related to the cultivation of heliconia as cut flower in terms of its methodological approach and research axes? And what is the spatial distribution in terms of contributions by country?

\section{Materials and Methods}

A bibliographic search was conducted in Scopus, Web of science and SciELO in January 10, 2020. The inquiry in Scopus was using the word "tropical flower", 94 documents were found (mainly articles, reviews, notes, books and book chapters). Selecting only scientific articles where the crop studied was heliconias, a total of 72 documents were compiled. The Web of Science consultation, the word "tropical flower" was used, yielded a total of 33 scientific articles. Selecting those related to the cultivation of heliconias with a final list of 14 documents. In the case of the SciELO, the word "Heliconias" was used. The database yielded 42 documents (mainly articles, reviews, notes) and only articles were used. The final compilation was 39 documents.

The three databases were reviewed to eliminate repeated documents in order to have a clean, single database. This generated a database in Excel with the bibliographic information of the documents $(\mathrm{N}=111)$, with the authors name, title, publication year, document type, summary, link and the digital object identifier (DOI). The last two were used to download the complete PDF documents. For the analysis of the information, a textual analysis was conducted in documents by a priori analysis categories (GallardoLópez et al., 2018) such as methodological approach, research axes, year, countries and varieties-cultivars (Table 1). NVivo 11 Pro software was used for Windows (Nvivo, 2011) applying the content analysis technique and using quotes (Verbeke et al., 2015). A classification was used for methodological approaches according to Meredith et al. (1989). 
Table 1. Categories description for the textual analysis of the research in heliconias

\begin{tabular}{|c|c|}
\hline Elements & Categories \\
\hline \multirow[t]{2}{*}{$\begin{array}{l}\text { Methodological } \\
\text { approach (Meredith } \\
\text { et al., 1989) }\end{array}$} & $\begin{array}{l}\text { Quantitative: intensive statistical analysis to identify factors, clusters } \\
\text { and other such relationships in a statistically significant way. } \\
\text { Qualitative: detailed description, which can lead to a better } \\
\text { understanding. }\end{array}$ \\
\hline & $\begin{array}{l}\text { Mixed: combination of the quantitative and qualitative approaches for } \\
\text { the analysis and understanding of the phenomenon. }\end{array}$ \\
\hline \multirow{3}{*}{$\begin{array}{l}\text { Axes of research } \\
\text { (Rodríguez, 2013; } \\
\text { Loges et al., 2015) }\end{array}$} & $\begin{array}{l}\text { Productive: substrate, fertilization, pests and diseases, irrigation, in vitro } \\
\text { crops, propagation, genetic diversity, plantation density, yield, cultural } \\
\text { tasks (management), wastewater treatments. }\end{array}$ \\
\hline & $\begin{array}{l}\text { Postharvest: pulse solutions, storage, packaging, size, weight, health, } \\
\text { vigor, color. }\end{array}$ \\
\hline & $\begin{array}{l}\text { Market: market acceptance, market price, novel appearance of } \\
\text { inflorescence and distribution of heliconia. }\end{array}$ \\
\hline Year & Period in which scientific contributions were made \\
\hline Countries & Country where scientific contributions were made \\
\hline Heliconias & Species used in research \\
\hline
\end{tabular}

\section{Results and discussion}

\section{Methodological approaches}

According to the total of codified elements $(\mathrm{N}=108)$ $98.1 \%$ corresponds to a quantitative approach, followed by mixed approach (1.9\%) with incipient contributions and absence of the qualitative approach. Scientific contributions are oriented towards a single approach. Therefore, it is required to conduct research in the qualitative and mixed approaches due to the economic and social importance of this ornamental and considering the challenges that the production and marketing processes imply. It is clear that the paradigm on which these methodologies are based, although useful, limits the types of questions that researchers can ask themselves (Meredith et al., 1989). In that sense, data collection methods that support the theories from which the hypotheses arise are required, since qualitative and quantitative approaches are required for the contrast of these. Both are complementary depending on the aim of the study, to whom the information will benefit and what social problem it solves (Cadena-Iñiguez et al., 2017).

The quantitative approach is related to experimental research, mainly corresponding to surveys and fieldlaboratory experiments. Due to the absence of the qualitative approach in the sector, it is important to redirect in this area since the understanding of different perspectives of agriculture are required. It should be directed to the use of paradigms where social actors, their development and the impacts of their social tasks, are considered the main axis (Gallardo-López et al., 2018). This is consistent with the development of scientific research in the last 50-60 years which has encouraged highly productive and profitable agriculture with significant environmental and social consequences (Sarandón, 2019).
The methodology should be considered as a flexible tool that allows information to be related and facilitates the construction of relevant conclusions for the formulation of cooperation and collaboration policies. This strengthen emerging networks and lead to their consolidation and irreversibility (Castro and Bohórquez, 2005). Hence, it can no longer be studied under the dominant quantitative paradigm but search for answers with mixed and qualitative approaches. Both methods require intent and systematize information. The use of instruments in the quantitative approaches guides the investigation whereas in the qualitative ones they are the processes. The approach to be used, qualitative, quantitative or a combination, is at the discretion of the researcher (Cadena-Iñiguez et al., 2017).

\section{Research axes}

The coded elements $(\mathrm{N}=118)$ show that $74.6 \%$ correspond to the production research axis, $16.1 \%$ postharvest, $6.8 \%$ market, and $2.5 \%$ industry used product.

\section{Production}

The subcategories in the production axis are fertilization and plant nutrition, genetic resources, pests, diseases, propagation, irrigation, wastewater treatments and shading percentages. In general, the investigations of this axis are studied under a quantitative approach.

From the textual quotations coded for the topic of plant fertilization and nutrition, it was founded that the authors recommend the use of organomineral fertilization (combination of organic fertilizers with mineral fertilizer) since it better promotes the growth and development of heliconias (Albuquerque et al., 2010; BeckmannCavalcante et al., 2011; Carvalho et al., 2012; Farias et al., 2013; Linares-Gabriel et al., 2018). Research was also 
focused on the use of silicon as it increases production and decreases the deterioration of heliconia inflorescences (Paulino et al., 2013; Albuquerque et al., 2014) and the use of nitrate and ammonium in hydroponic conditions (Gómez-Merino et al., 2012). Other authors analyzed macronutrient deficiencies and their effect in production (Castro et al., 2015).

For the topic of genetic resources, the authors made contributions to the study of more than 20 heliconia genotypes in order to determine the commercial potential as cut flower in the tropical flower industry (Loges et al., 2007; Costa et al., 2009; Rocha et al., 2010; Merida et al., 2013; Araujo et al., 2015; Loges et al., 2015; Pereira et al., 2016). Also the study of the morphology and genetic variability of this species (Hapsari et al., 2019; Kannan et al., 2019; Raizer et al., 2019) and the ability to adapt to different edaphoclimatic conditions (Tokarz et al., 2019).

Studies in the topic of pests and diseases were related to the incidence and severity in cultivation of heliconia caused by pathogens such as $F$. oxysporum $f$. sp. cubense, Pseudocercospora fijiensis; nematodes of the genus Meloidogyne, Helicotylenchus erythrinae, H. crenacauda, H. dihystera, Meloidogyne incognita, Pratylenchus zeae and Rotylenchulus reniformis, defoliators such as Cornops frenatum frenatum and mites, particularly specimens of Tropicoseius venezuelensis Baker \& Yunker (Castro et al., 2008; Lemos et al., 2010; Sardinha et al., 2012; Sobrinho et al., 2012; Britto et al., 2015; Vázquez-Euán et al., 2019). Despite the affectations some authors recommend that the use of synthetic insecticides should be done only in extreme cases (Lemos et al., 2010).

Regarding propagation, the studies were oriented to the use of growth regulators (BAP and NAA) in culture medium as this favors an increase in sprouts and it is possible to obtain satisfactory levels of propagation in heliconia cultivars (Raizer et al., 2015; Rodrigues et al., 2016). Tillering was also evaluated in relation to the efficiency of water use, harvested flower stems, relationship of harvested stems and number of tillers, among other variables (Coelho et al., 2019).

A relevant and scarce information topic was irrigation. The efficient use of water has been studied (Gervásio et al., 2017) and use of heliconia as alternative for the control of wastewater contamination. In the latter mentioned, heliconias are used in high-speed artificial wetlands that use artificial carriers for bacterial growth as a support medium in a process of phytodepuration against emerging contaminants (Peña-Salamanca et al., 2013; Atalla et al., 2019; Cano et al., 2019; Corzo and Sanabria, 2019; Oliveira et al., 2019; PérezSalazar et al., 2019; Sandoval et al., 2019; Cano et al., 2020).

For topical conditions, the importance of the percentages of shade for the cultivation of heliconias is highlighted because it develops better in these conditions which influences the content of photosynthesized pigments and the growth (Gomes et al., 2016; Souza et al., 2016). E.g. heliconias grown under the lowest photosynthetically active radiation (PAR) $(30 \%$ to $35 \%$ of the open condition), show improved growth with increased biomass accumulation, plant height, sucking habit, appearance of flowering shoots, yield inflorescence and light use efficiency (Nihad et al., 2019).
This crop must be oriented towards sustainable production, in terms of non-dependence on agro-toxic's. In the context of flower production, there is a high contamination by pesticides, agricultural waste (from inputs) and high doses of fertilization. The latter is one of the main activities in floriculture and occupies an important line in product costs (Cortes et al., 2017). Consequently, environmental impacts on water bodies, soil and on the health of workers (among others) when using these products.

Plants are grown under 50\% shading conditions; it is optimally suited to achieve the desired establishment and growth. Due to this characteristic, this crop does not replace flora and fauna in established areas (cutting down trees, e.g.), as is the case with monocultures, since many heliconia species are found in humid tropical forests (Cantor et al., 2014).

This species harbors a diversity of organisms beneficial to the environment (Benítez-Malvido et al., 2019; Janeček et al., 2019), and provide an ideal habitat for the development of the biological cycle of some insects corresponding to the orders: Diptera, Coleoptera, Himenoptera y Hemiptera, due to the different phenological, structural and environmental conditions generated in the crops (Henao and Ospina, 2008; Foottit and Maw, 2019). Furthermore, these species are mainly pollinated by hummingbirds and bats (Temeles and Bishop, 2019; Temeles et al., 2019; Torres-Vanegas et al., 2019). The latter are used by heliconia plants for reproduction and survival; rolled tubular sheets provide microclimatic conditions suitable for tropical species and benefit camouflage (Pérez-Cárdenas et al., 2019; Rodríguez-Herrera et al., 2019).

Due to the above characteristics in the production process of this species, chemical and organic fertilizers can be supplemented. In this way, production is increased, the soil is protected, a unique environment for tropical fauna is generated, and production costs are mainly reduced as a result of low doses of mineral fertilizer. The above suggests the use of a combination of both amendments in this crop (Linares-Gabriel et al., 2017a; Linares-Gabriel et al., 2018).

\section{Postharvest}

Contributions in this category are related to pulse solutions, storage and characterization of commercial stems. According to the quotes cited for the topic pulse solutions, the studies focused on the use of sucrose, silver nitrate, calcium chloride, gibberellic acid, citric acid, and organic aloe vera solutions (Aloe vera barbadensis) and moringa (Moringa oleifera Lam.), as medium of preserving flower stems (Costa, 2015; Malakar et al., 2019; Sardinha et al., 2019; Shokalu et al., 2019). The hardiness of this species has also been compared with rose stems in terms of resistance to moisture loss (Leyva-Ovalle et al., 2011). As well as the use of organophosphate insecticides for the control of insects in the flower stems of heliconia (Oliveira et al., 2012).

Regarding the storage topic, the contributions recommend a temperature that ranges from 10 to $19{ }^{\circ} \mathrm{C}$, ideal for storing heliconia flower stems for up to eight days on average (Costa et al., 2011a; Costa et al., 2011b; 
Costa et al., 2015; Darras, 2019; Silva et al., 2019). Other authors recommend an in-depth study that uses techniques to confirm or reject the sensitivity of heliconia to ethylene (Bañuelos-Hernández et al., 2016). In relation to the characterization of commercial stems, it is recommended that heliconia genotypes are suitable for use in landscaping projects (Loges et al., 2016).

\section{Storage}

In general, the storage of heliconias has been little studied. Despite this, a particular characteristic of this ornamental is its rusticity, while temperate flowers are stored at temperatures above the freezing point. The recommended temperature for the transport and storage of heliconias is around $10{ }^{\circ} \mathrm{C}$ as they are sensitive to damage by cold. It is recommended to wax the stems to maintain the appearance of the flower stem (Alvarado et al., 2019).

The heliconia stems pulsed with $10 \%$ sucrose for 60 minutes maintain the quality of the inflorescences. This treatment allows the stems to reach up to 20 days of longevity, showing the color and brightness appropriate to quality standards (Costa, 2015). Some authors recommend dry treatment in heliconia as an alternative, guaranteeing a reduction in the excessive use of water (Linares-Gabriel et al., 2019). The results place this research axis in second place with an intermediate level of scientific contributions.

\section{Market}

For the market issues, a low level of research was found for the quantitative, qualitative and mixed research approaches. The analyzed research shows subcategories in relation to market exploration work and species with economic potential, as well as economic and financial analysis.

For the topic of market exploration and species with economic potential, contributions were found on desirable characteristics identified by heliconia producers such as adequate length, size, color, durability, shipping capacity, etc. This is the result of an interesting market segment for the development of regional productive alternatives that guarantee the continuity of traditional populations in the field with direct effect on the local economy (Pizano, 2005; Aranda et al., 2007; Arruda et al., 2008).

Other investigations are oriented towards obtaining information to coordinate with flower markets, species with longer flowering periods. In this sense, the most important criteria for selecting cultivars are production throughout the year, market acceptance, long-term postharvest durability, production during the short period in the region, low maintenance requirement, best market price, adequacy of the packed inflorescence when considering the size and weight, and finally the novel appearance of the inflorescence (Criley, 2000; Loges et al., 2015).

Contributions in relation to economic and financial analysis, address profitability indicators, administrative planning, and management actions specifically in the territory of Rio de Janeiro (Neto et al., 2011). No information was found on export and import of this commercial segment especially, detailed statistics on national and international trade in species of this type of flower.
The current situation of the production of heliconias demands research that addresses the following dimensions: social, economic, market, cultural and financial. However, the dominant axis of research is production. The deficiency in terms of research in the market category prioritizes the focus of attention due to the commercial importance of this ornamental (Castro and Bohórquez, 2005).

\section{Industry used product}

Interesting and innovative contributions were found in relation to the use and transformation of heliconias, e.g. for medical use. Some authors evaluated two species of heliconia: Heliconia psittacorum and Heliconia rostrata against the indirect hemolytic, proteolytic and coagulant activities of the venom of Bothrops asper. This shows that the heliconia extracts delay the coagulant effect of the venom with respect to the positive control up to 45.59 seconds (Pereañez et al., 2008; Estrada et al., 2009). Heliconia rostrata was used for the treatment of skin cancer. The authors of this work estimated the cytotoxicity activity of the petroleum ether extracts of the rhizomes (PER) and the inflorescence (PEF) of Heliconia rostrata, without causing any potential risk to human health. (Roy et al., 2019). The mechanical tensile properties of the fibers obtained from the stem of Heliconia bihai were also evaluated and is compared with the tensile properties of other lignocellulosic fibers (Quinaya and D'almeida, 2019).

These last contributions make the difference between the other categories of analysis which means that the study of heliconias is new by scientists. Besides that, the importance of this species is not only as a cut flower but the fact that technological advances consider it as an innovative product in various sectors of the industry.

\section{Research period}

The studies analyzed comprise the period from 1990 to 2020. The intention of considering this period was to visualize the chronological advance in relation to the scientific contributions. Differences of the research axes were found in terms of time. The greatest number of investigations was reflected in the period 2011-2020 (72.5\%), followed by the period 2003-2010 (25.7\%) and for the beginning of the 90's and 2000's the investigation represented $1.8 \%$. This temporary distribution of contributions is related to the origins of Heliconia Society International in 1986 (Castro and Bohórquez, 2005) and the economic and market boom after 2003. This economic importance was manifested in the introduction of this exotic species in the flower trade in recent decades, when it was recognized as an ornamental variety of unusual elegance (Cantor et al., 2014).

\section{Countries}

The countries with the highest number of investigations are: Brazil with 54.5\%, Colombia $15.5 \%$ and Mexico $10.9 \%$. In a lower percentage USA (3.6\%), Costa Rica and India with $2.7 \%$ respectively; Canada $1.8 \%$ and for the rest of countries, $0.9 \%$ (Figure 1 ). 


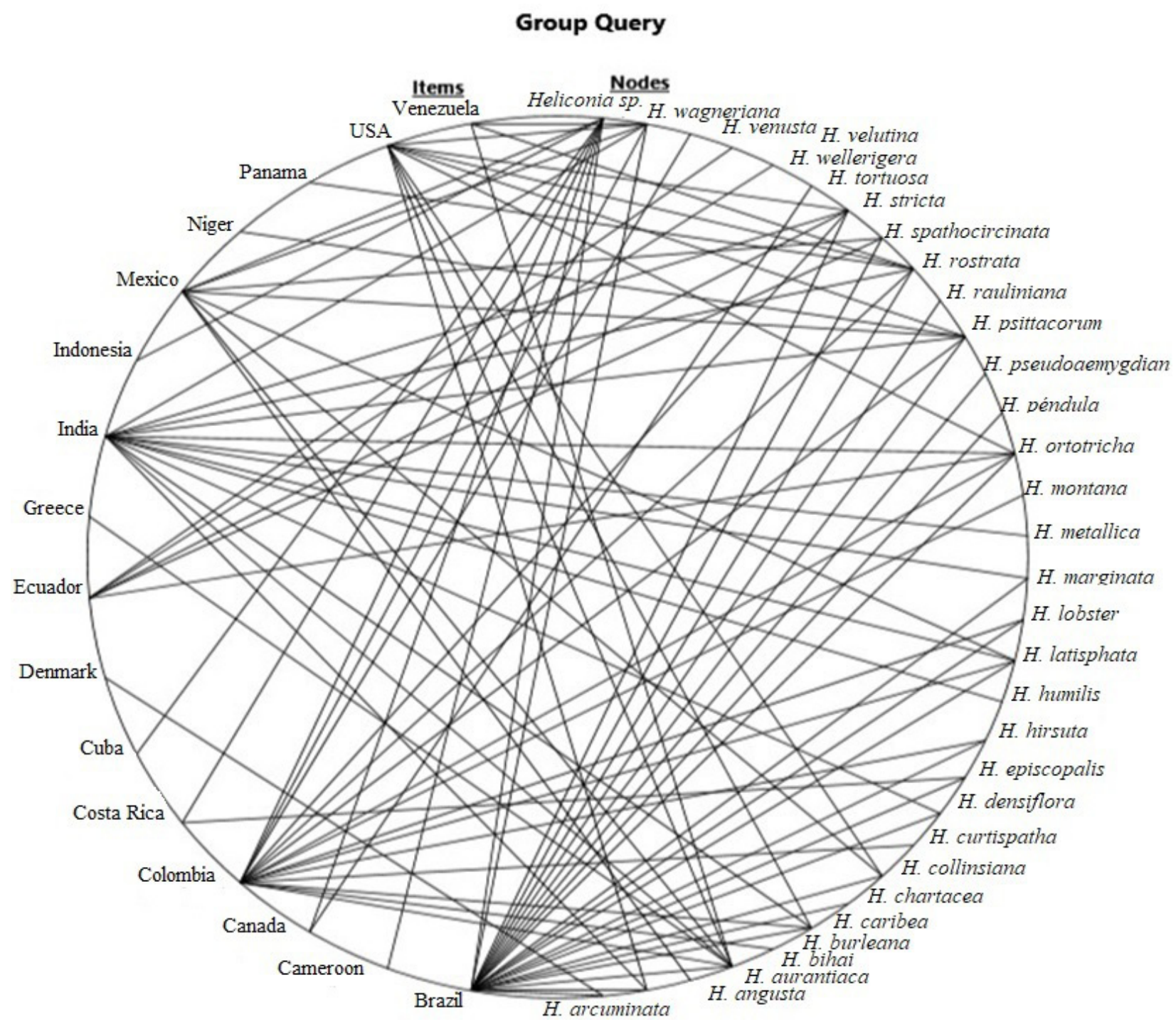

Figure 1. Countries with scientific contributions in different species of Heliconia spp.

This spatial distribution is due to its natural center of origin where heliconias present very defined agro-ecological requirements in these areas with high temperatures and abundant rainfall inherent to tropical countries (Jerez, 2007). For instance, heliconias are perennial plants that flower from March to October and for an optimal growth and development requires temperatures ranging from 15 to $25{ }^{\circ} \mathrm{C}$. Plants need a minimum of 6-8 light-hours per day for flowering, otherwise they will develop lush foliage (Cantor et al., 2014).

Commercial floriculture practiced in Brazil is concentrated in the state of São Paulo (48.9\%) particularly, in the geographical regions around the municipalities of Atibaia and Holambra. In these regions the offer is organized. In the state of São Paulo floriculture is practiced by associate producers and members of the Cooperative Veiling Holambra and Cooperative Cooperflora, located in the cities Santo Antonio de Posse and Holambra, respectively (Junqueira and Peetz, 2018).

Brazil is a consolidated country in terms of scientific progress with the highest number of contributions from the productive, post-harvest and market axis. The advances in the market are due to investigations regarding propagation, fertilization, productivity, genotype characterization, irrigation and in vitro cultures. These determine the development in the floricultural area.

In Colombia, tropical flowers are an object of concern for some Colombian researchers who have worked on their identification, taxonomy, characterization, domestication, propagation and cultivation in regions with high potential for conservation, planting and development as a commercial alternative (Castro and Bohórquez, 2005). The Colombian tropical flower marketing initiative towards explored markets is highly viable (Aranda et al., 2007).

In Mexico, there is a low presence in research. In relation to the market, a study by Hernández and AvitiaRodríguez (2017) found that the percentage participation of exports and imports of Mexican floriculture represent less than half a point. Besides that, floriculture in general presents a situation of general worsening in trade dynamics. These authors emphasize that the economic opening of the Mexican floriculture is low, reduced every time and 
the importing sector is more open than the exporting one. In Mexico, heliconias are considered the newest among tropical species (Tlahuextl-Tlaxcalteca et al., 2005). The type of commercialization is internal, e.g. producers from the state of Chiapas are those who distribute Heliconia wagneriana cv. Peterson, Heliconia wagneriana var. Rainbow, Heliconia psittacorum x spathorcinata tropics and Heliconia collinsiana $\mathrm{x}$ bourgaeana are distributed in southeastern regions and mostly in the supply centers of the state of Puebla and Mexico City (Linares-Gabriel et al., 2017b).

The USA has a low level of scientific input and it is oriented to commercial producer sales records, to identify the high flowering seasons and the length of the flowering season (Criley, 2000). In Cuba, heliconias are an important alternative within the commercialization of ornamental plants. Considering the little knowledge of the producers and the country, the possibility of conducting new investigations that allow increasing the introduction of this plant is mediated (Rodríguez, 2013).

Venezuela has potential for sale but it does not as a producer, for the supply of heliconias. For this reason, in the heliconia marketing structure in Venezuelan cities, the majority supply takes place through distributors (63\%) and through producers $(33 \%)$. The important supply centers are the cities of Valencia, Carabobo and Maracaibo (Aranda et al., 2007). For the other countries the scientific information is incipient and relevant data regarding production and marketing are not presented, unlike in other countries.

In general, countries with tropical regions carry out a greater number of investigations. However, the target population or "final consumer" is European and most of its supply of tropical flowers, including heliconia, comes from Europe which are produced in greenhouses, mainly in the Netherlands, France and Italy. This is due to high transportation costs and producing them close to the final consumer gives producers a competitive advantage (C.B.I., 2016).

\section{Heliconias}

In relation to the species in which research is carried out, $54.9 \%(\mathrm{~N}=260)$ are oriented to $H$. psittacorum, $H$. bihai, $H$. spathocircinata, $H$. rostrata and $H$. caribea. These results are similar to those reported by Cantor et al. (2014), they mention that the most requested species for sale are: Heliconia bihai, Heliconia stricta, Heliconia caribaea and Heliconia chartacea.

The species with the highest demand, in relation to the number of scientific contributions are: H. psittacorum, $H$. bihai, $H$. spathocircinata, $H$. wagneriana, $H$. rostrata and $H$. caribea. The case Heliconia wagneriana, is in the markets of Mexico and it is a trend among tropical flowers (Tlahuextl-Tlaxcalteca et al., 2005).

The characteristics mentioned distinguish the size of the flower arrangements (Linares-Gabriel et al., 2017b). Heliconia flower compositions are used alone or in combination with other exotic, delicate and elegant species (Cantor et al., 2014). Tropical flowers are mainly sold in mixed bouquets, in which various flowers are mixed with green leaves and fillings to produce a colorful bouquet.

\section{Interactions between analysis categories}

The results show interactions between methodological approaches, research axes and heliconia types. Contributions are aligned to the quantitative approach. The production research axis stands out the species: $H$. psittacorum, $H$. bihai, $H$. spathocircinata, $H$. rostrata and $H$. caribea, to mention the most important, although research has been carried out on most of these species. Interactions were found between the quantitative, postharvest approach and the types of Heliconias studied which includes: $H$. wagneriana, $H$. stricata, $H$. spathocircinata, $H$. rostrata, $H$. psittacorum, $H$. latispatha, $H$. irsuta, $H$. caribea and $H$. bihai. The market category is related to the mixed and quantitative approach and to the species: $H$. wagneriana, $H$. stricata, $H$. spathocircinata, $H$. rostrata, H. psittacorum, H. marginata, H. latispatha, H. irsuta, $H$. densiflora, H.collinsiana, $H$. chartacea, $H$. caribea, $H$. bihai, $H$. angusta and $H$. acuminata. These interactions are the result of the relationship between analyzed categories and the number of coded text quotes (Figure 2). 


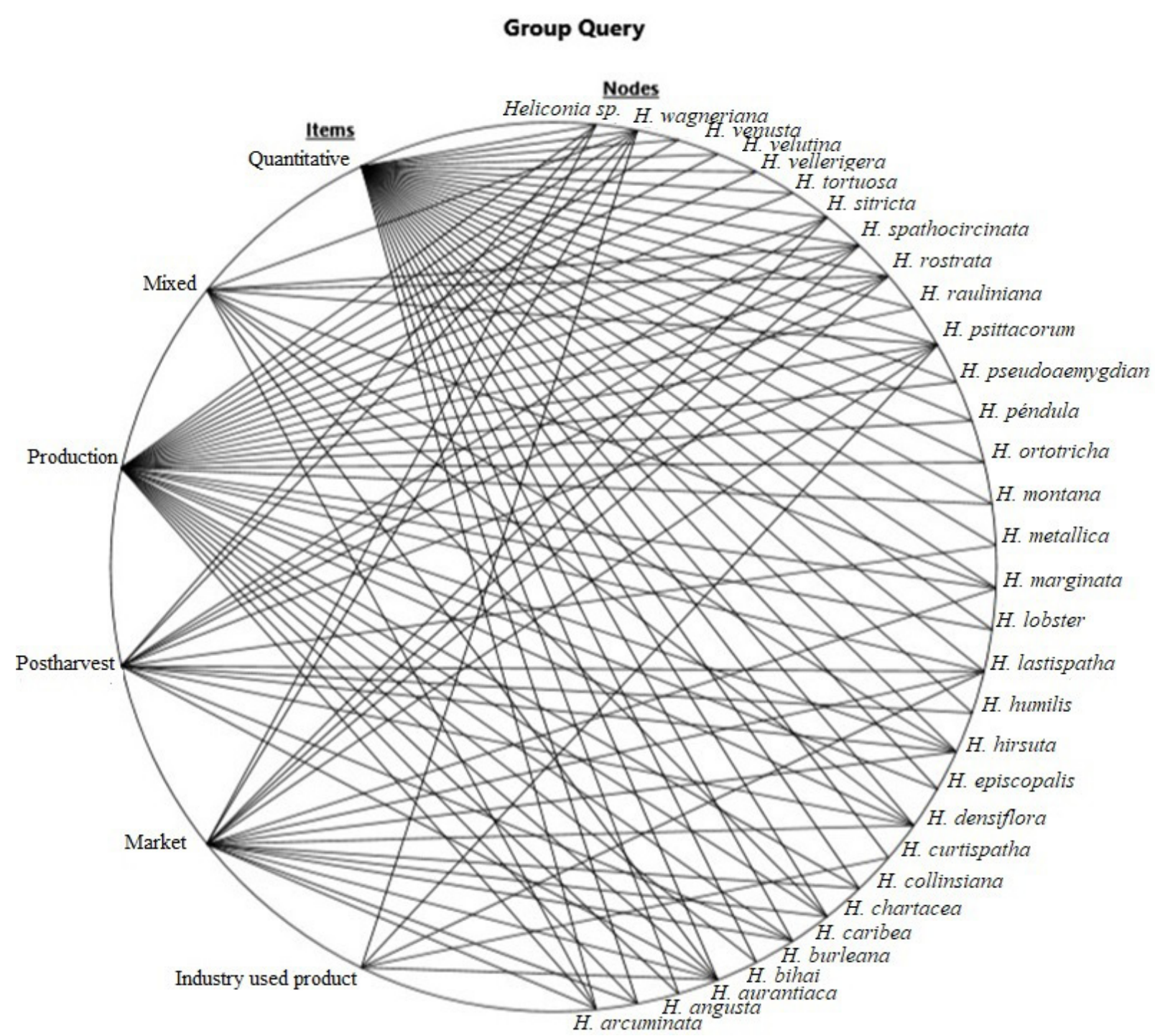

Figure 2. Interaction between categories and Heliconia species.

Brazil and Colombia have an important quantitative and mixed methodological approaches. The contributions are in relation to production, postharvest and market. On the contrary, in Mexico the investigations are directed towards the quantitative methodological approach and their contributions are directed to production and postharvest. Costa Rica performs more to quantitative work specifically in production. Venezuela is oriented to a mixed approach and research axis related to the market. Cuba has a preference for quantitative approach and its research axes are production, postharvest and market. Lastly, USA uses a production and market oriented quantitative approach. In relation to the total species found in the review, Brazil is the leading country in scientific contributions $(100 \%)$ in the analyzed axes, according to the textual citations, followed by Colombia $52.3 \%$, USA $42.8 \%$, and Mexico $23.8 \%$.

\section{Conclusions}

The scientific contributions in heliconias derived from quantitative approach. The production category has a greater presence in relation to the postharvest and market subcategories. In regard to the complexity of producing and marketing heliconias, it is necessary to approach research with qualitative and mixed approaches with marketoriented research axes.

The countries that make the most scientific contributions are Brazil, Colombia, and Mexico that have been shown an increase in the last decade. This does not mean that these countries with agroecological potential are pioneers in the production and commercialization of heliconias, with the exception of Colombia, which is already a consolidated country in terms of flower exports. The most important species are $H$. psittacorum, H. bihai, $H$. spathocircinata, $H$. wagneriana, $H$. rostrata and $H$. caribeaue due to its economic and agronomic relevance.

This work identified problems and potentialities in the research axes analyzed. However, aspects of commercialization and its social dynamics have not yet been studied in depth. In addition, there is a gap in the generation of knowledge about the context of tropical floriculture and the role of heliconias as an emerging product in research and the market. In addition, specific statistics on the import and export of this species, both as cut flower or transformed 
(industry used product). Finally, it is important to consider the social, economic, productive and environmental dimensions of the cultivation of heliconias. This species cannot be studied from the current disciplinary limits. This research must be approached from paradigms where social actors (farmers), their development and the impacts of their social tasks on the cultivation of heliconia are considered the main axis.

\section{Author Contribution}

ALG, FGL, MV, CLS and GLR: Research design and writing of manuscript.

\section{References}

ALBUQUERQUE, A.W.; SANTOS, J.M.; FARIAS, A.P. Produtividade e qualidade pós-colheita de Helicônia Golden Torch submetida a fontes e doses de silício. Revista Brasileira de Engenharia Agrícola e Ambiental - Agriambi, v.18, n.2, p.173-179, 2014. DOI: 10.1590/ S1415-43662014000200007.

ALBUQUERQUE, A.W.; ROCHA, E.S.; COSTA, J.P.V.; FARIAS, A.P.; BASTOS, A.L. Produção de helicônia golden torch influenciada pela adubação mineral e orgânica. Revista Brasileira de Engenharia Agricola e Ambiental, v.14, n.10, p.1052-1058, 2010. DOI: http:// dx.doi.org/10.1590/S1415-43662010001000005

ALVARADO, G.C.; ARÉVALO GALARZA, M.L.; VELASCO VELASCO, J.; BALTAZAR BERNAL, O.; SALINAS RUÍZ, J. Effect of waxing, cold storage and salicylic acid on the quality and vase life of Heliconia wagneriana. Acta Horticulturae, v.1237, p.221-226, 2019. DOI: 10.17660/ActaHortic.2019.1237.29.

ARANDA, Y.; BELLO, J.; MONTOYA, I. Exploración del mercado de heliconias en el segmento de consumo intermedio en las ciudades de Arauca (Colombia) y Acarigua y Caracas (Venezuela). Agronomía Colombiana, v.25, n.1, p.189-196, 2007.

ARAUJO, P.G.P.; LEITE, K.P.; SILVA, S.S.L.; BASTOS, S.M.S.L.; CASTRO, A.C.R.; LOGES, V. Morphological aspects in Heliconia chartacea Lane ex Barreiros inflorescences for use as cut flower. Acta Horticulturae, v.1087, p.249-253, 2015. DOI: 10.17660/ ActaHortic.2015.1087.31

ARRUDA, R.; CARVALHO, V.T.D.; ANDRADE, P.C.M.; PINTO, M.G. Hêliconias como alternativa econômica para comunidades amazônicas. Acta Amazonica, v.38, n.4, p.611-616, 2008. DOI: 10.1590/S004459672008000400003.
ATALlA, A.; PELISSARI, C.; OLIVEIRA, M.; SOUZA PEREIRA, M.A.; CAVALHERI, P.S.; SEZERINO, P.H.; CORREA MAGALHÃES FILHO, F.J. Influence of earthworm presence and hydraulic loading rate on the performance of vertical flow constructed wetlands. Environmental Technology, p.1-24, 2019. DOI: https:// doi.org/10.1080/09593330.2019.1710572.

BAÑUELOS-HERNÁNDEZ， K.P.; GARCÍA-NAVA, J.R.; LEYVA-OVALLE, O.R.; PEÑA-VALDIVIA, C.B.; YBARRA-MONCADA, M.C. Flowering stem storage of Heliconia psittacorum L.f. cv. Tropical. Postharvest Biology and Technology, v.112, p.159-169, 2016. DOI: 10.1016/j.postharvbio.2015.10.006.

BECKMANN-CAVALCANTE, M.Z.; AMARAL, G.C.; SILVA, A.A.; CAVALCANTE, Í.H.L.; LIMA, M.P.D. Alternative substrates for production of Heliconia psittacorum L. seedlings under shade and open field conditions. African Journal of Biotechnology, v.10, n.68, p.15272-15277, 2011. DOI: http://dx.doi.org/10.5897/ AJB11.1028

BENÍTEZ-MALVIDO, J.; MARTÍNEZ-FALCÓN, A.P.; DURÁN-BARRÓN, C.G. Diversity metrics of spider communities associated with an understorey plant in tropical rain forest fragments. Journal of Tropical Ecology, v.36, n.2, p.47-55, 2019. DOI: https://doi. org/10.1017/S026646741900035X.

BRITTO, E.P.J.; FINOTTI, A.S.; DE MORAES, G.J. Diversity and population dynamics of Ascidae, Blattisociidae and Melicharidae (Acari: Mesostigmata) in tropical flowers in Brazil. Experimental and Applied Acarology, v.66, n.2, p.203-217, 2015. DOI: 10.1007/ s10493-015-9904-5.

C.B.I. Fresh cut tropical flowers in the European market. Netherlands: Centre for the Promotion of Imports from Developing Countries, 2016. p.11.

CADENA-IÑIGUEZ, P.; RENDÓN-MEDEL， R.; AGUILAR-ÁVILA, J.; SALINAS-CRUZ, E.; DE LA CRUZ, F.D.R.; SANGERMAN-JARQUÍN, D.M. Métodos cuantitativos, métodos cualitativos o su combinación en la investigación: un acercamiento en las ciencias sociales. Revista Mexicana de Ciencias Agrícolas, v.8, n.7, p.1603-1617, 2017. DOI: https://doi.org/10.29312/ remexca.v8i7.515.

CANO, V.; VICH, D.V.; ANDRADE, H.H.; SALINAS, D.T.; NOLASCO, M.A. Nitrification in multistage horizontal flow treatment wetlands for landfill leachate treatment. Science of The Total Environment, v.704, p.135376, 2020. DOI: https://doi.org/10.1016/j. scitotenv.2019.135376. 
CANO, V.; VICH, D.V.; ROUSSEAU, D.P.; LENS, P.N.; NOLASCO, M.A. Influence of recirculation over COD and N-NH4 removals from landfill leachate by horizontal flow constructed treatment wetland. International journal of phytoremediation, v.21, n.10, p.998-1004, 2019. DOI: https://doi.org/10.1080/15226514.2019.1594681.

CANTOR, M.; SINGUREANU, V.; DENISA, H.; ERSZEBET, B. Heliconias-Novelties and applicability in floral art. Journal of Horticulture, Forestry and Biotechnology, n.1, p.22-27, 2014. DOI: http://journalhfb.usab-tm.ro/2014/Li.

CARVALHO, J.S.B.; MARTINS, J.D.L.; ULISSES, C.; SILVA, W.L. Adubação orgânica, mineral e organomineral e sua influencia no crescimento da helicônia em GaranhunsPE. Horticultura Brasileira, v.30, n.4, p.579-583, 2012. DOI: $10.1590 / \mathrm{S} 0102-05362012000400003$.

CASTRO, A.C.R.; WILLADINO, L.G.; LOGES, V.; CASTRO, M.F.A.; ARAGÃO, F.A.S. Macronutrients deficiency in Heliconia psittacorum $x$ Heliconia spathocircinata 'Golden Torch'. Revista Ciência Agronômica, v.46, p.258-265, 2015. DOI: 10.5935/18066690.20150005 .

CASTRO, L.A.O.; BOHÓRQUEZ, D.A.C. De la investigación al mercado: un acercamiento a la medición del impacto de las heliconias colombianas. Estudios Gerenciales, v.21, n.96, p.107-126, 2005-09 2005.

CASTRO, N.R.; COÊLHO, R.S.B.; LARANJEIRA, D.; COUTO, E.F.; DE SOUZA, M.B.R. Ocorrência, métodos de inoculação e agressividade de Fusarium oxysporum f. sp. cubense em Heliconia spp. Summa Phytopathologica, v.34, n.2, p.127-130, 2008. DOI: 10.1590/S010054052008000200003 .

COELHO, J.P.A.; GERVÁSIO, E.S.; SÁ, T.S.; CAVALCANTE, M.Z.B.; SOUZA, S.G. Management of tillering in the production of flower stems of heliconia cultivated in pots. Comunicata Scientiae, v.10, n.3, p.353363, 2019. DOI: https://doi.org/10.14295/cs.v10i3.2716.

CORTES JIMÉNEZ, S.; ETCHEVERS BARRA, J.D.; HIDALGO MORENO, C.M.; NAVARRO GARZA, H. Estado nutrimental del agroecosistema rosa (Rosa spp.) en la ladera este del Iztaccíhuatl. Terra Latinoamericana, v.35, n.3, p.237-246, 2017. DOI: http://dx.doi.org/10.28940/ terra.v35i3.132

CORZO, A.; SANABRIA, O. Adaptation of vegetation in high-rate constructed wetland using artificial carriers for bacterial growth: Assessment using phytopathological indicators. Journal of Water Process Engineering, v.32, p.100974, 2019. DOI: https://doi.org/10.1016/j. jwpe.2019.100974.
COSTA, A.S.; LEITE, K.P.; GOMES, R.J.; ARCELINO, E.C.; PESSOA, C.O.; LOGES, V. Chilling injury symptoms in species of heliconia. Acta Horticulturae, v.1060, p.5562, 2015. DOI: 10.17660/ActaHortic.2015.1060.7.

COSTA, A.S.; LOGES, V.; GUIMARÃES, W.N.R.; CASTRO, A.C.R.; NOGUEIRA, L.C. Heliconia genotypes under partial shade: II. Evaluation of flowering stems. Acta Horticulturae, v.813, p.171-176, 2009. DOI: 10.17660/ ActaHortic.2009.813.21.

COSTA, A.S.; NOGUEIRA, L.C.; DOS SANTOS, V.F.; CAMARA, T.R.; LOGES, V.; WILLADINO, L. Storage of cut Heliconia bihai (L.) cv. Lobster Claw flowers at low temperatures. Revista Brasileira de Engenharia Agricola e Ambiental, v.15, n.9, p.966-972, 2011a. DOI: 10.1590/ S1415-43662011000900013.

COSTA, A.S.; NOGUEIRA, L.C.; DOS SANTOS, V.F.; FINGER, F.L.; CAMARA, T.R.; LOGES, V.; WILLADINO, L. Characterization of symptoms of senescence and chilling injury on inflorescences of Heliconia bihai (L.) cv. Lobster Claw and cv. Halloween. Postharvest Biology and Technology v.59, n.1, p.103109, 2011b. DOI: 10.1016/j.postharvbio.2010.08.015.

COSTA, R.R.; COSTA, L.C.; CARNEIRO, G.G.; RIBEIRO, W.S.; BARBOSA, J.A.; FINGER, F.L. Postharvest quality of Heliconia wagneriana pulsed with sucrose. Acta Horticulturae, v.1060, p.201-206, 2015. DOI: 10.17660/ActaHortic.2015.1060.29.

CRILEY, R.A. Seasonal flowering patterns for heliconia shown by grower records. Acta Horticulturae, v.541, p.159-165, 2000. DOI: 10.17660/ActaHortic.2000.541.22.

DARRAS, A.I. The chilling injury effect in cut flowers: a brief review. The Journal of Horticultural Science and Biotechnology, v.95, n.1, p.1-7, 2019. DOI: https://doi.org /10.1080/14620316.2019.1629340.

ESTRADA, S.; QUINTANA, J.C.; JIMÉNEZ, S.L.; ALARCON, J.C.; PEREAÑEZ, J.A.; VARGAS, L.J. Evaluación fitoquímica preliminar de Heliconia psittacorum y Heliconia rostrata y de la potencial actividad inhibitoria de algunos de los efectos del veneno de Bothrops asper (mapaná X). Vitae, v.16, n.2, p.252-257, 2009.

FARIAS, A.P.; DE ALBUQUERQUE, A.W.; FILHO, G.M.; REIS, L.S. Produtividade da Heliconia psittacorum $x$ Heliconia pathocircinada cv. Golden Torch sob diferentes fontes de adubação orgânica. Revista Brasileira de Engenharia Agricola e Ambiental, v.17, n.7, p.713720, 2013. DOI: http://dx.doi.org/10.1590/S141543662013000700004 . 
FOOTTIT, R.; MAW, H. Geographic distribution, host preferences and molecular diversity within the genus Pentalonia (Hemiptera: Aphididae). Zootaxa, v.4701, n.4, p.383-391, 2019. DOI: http://dx.doi.org/10.11646/ zootaxa.4701.4.4.

GALLARDO-LÓPEZ， F.; HERNÁNDEZ-CHONTAL, M.; CISNEROS-SAGUILÁN, P.; LINARES-GABRIEL, A. Development of the concept of Agroecology in Europe: A Review. Sustainability, v.10, n.4, p.1210, 2018. DOI: https://doi.org/10.3390/su10041210.

GERVÁSIO, E.S.; ISHIKAWA, F.H.; DA SILVA, V.D.; DE MELO JÚNIOR, J.C.F. Water levels depletion in substrate in the development of Heliconia psittacorum L. F. cv. Red Opal. IRRIGA, v.22, n.1, p.44-58, 2017. DOI: https://doi. org/10.15809/irriga.2017v22n1p44-58.

GOMES, R.J.; GUISELINI, C.; SIQUEIRA, G.M.; ALBUQUERQUE FILHO, J.C.C.; LOGES, V.; PANDORFI, H. Temporal stability of Heliconia spp. flower stem production. Ornamental Horticulture, v.22, n.3, p.318-325, 2016. DOI: https://doi.org/10.14295/ oh.v22i3.943.

GÓMEZ-MERINO, F.C.; TREJO-TÉLLEZ, L.I.; VIDALMORALES, B. Heliconia psittacorum responds to variations of nitrate/ammonium ratios under hydroponic conditions. Acta Horticulturae, v.947, p.261-268, 2012. DOI: 10.17660/ActaHortic.2012.947.33.

HAPSARI, L.; TRIMANTO, T.; WAHYUDI, D. Species diversity and phylogenetic analysis of Heliconia spp. collections of Purwodadi Botanic Garden (East Java, Indonesia) inferred by rbcL gene sequences. Biodiversitas, v.20, n.5, p.1266-1283, 2019.

HENAO, E.R.; OSPINA, K.A. Inséctos benéficos asociados a cultivos de heliconias en el eje cafetero colombiano. Boletín Científico. Centro de Museos. Museo de Historia Natural, v.12, n.1, p.157-166, 2008.

HERNÁNDEZ， J.J.R.; AVITIA-RODRÍGUEZ， J.A. Foricultura mexicana en el siglo XXI: Su desempeño en los mercados internacionales Revista de Economía, v.34, n.88, 2017. DOI: http://hdl.handle.net/20.500.11799/68158.

HERNÁNDEZ, M.E.O. Entre la competitividad local y la competitividad global: floricultura comercial en el Estado de México. Convergencia, v.14, n.45, p.111-160, 2007.

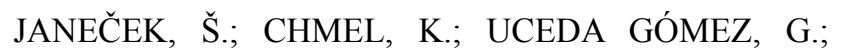
JANEČKOVÁ, P.; CHMELOVÁ, E.; SEJFOVÁ, Z.; LUMA EWOME, F. Ecological fitting is a sufficient driver of tight interactions between sunbirds and ornithophilous plants. Ecology and Evolution, v.10, n.4, p.1784-1793, 2019. DOI: https://doi.org/10.1002/ece3.5942.
JEREZ, E. El cultivo de las Heliconias. Cultivos tropicales, v.28, n.1, 2007. DOI: http://www.redalyc.org/articulo. oa? id=193215858005.

JUNQUEIRA, A.H.; PEETZ, M.S. Sustainability in Brazilian floriculture: introductory notes to a systemic approach. Ornamental Horticulture, v.24, n.2, p.155162, 2018. DOI: http://dx.doi.org/10.14295/oh.v24i2.1253. KANNAN, M.; JAWAHARLAL, M.; RANCHANA, P. Evaluation of Heliconia genotypes for genetic, yield and quality parameters. Acta Horticulturae, v.1241, p.209214, 2019. DOI: 10.17660/ActaHortic.2019.1241.29.

LEMOS, W.D.P.; RIBEIRO, R.C.; LHANO, M.G.; DA SILVA, J.P.S.; ZANUNCIO, J.C. Cornops frenatum frenatum (Marschall)(Orthoptera: Acrididae, Leptysminae) in crops of tropical flowers of Heliconia spp. in the State of Pará, Brazil. Entomotropica, v.25, n.1, p.43-47, 2010.

LEYVA-OVALLE，O.R.; RODRÍGUEZ-GOYA, A.Y.; HERRERA-CORREDOR, J.A.; GALINDO-TOVAR, M.E.; MURGUÍA-GONZÁLEZ, J. Polímero hidrofílico combinado con soluciones preservadoras en la vida de florero de tallos florales de rosa y heliconia. Tropical and Subtropical Agroecosystems, v.13, n.3, 2011.

LINARES-GABRIEL, A.; LÓPEZ-COLLADO, C.J.; HERNÁNDEZ-CHONTAL, M.A.; VELASCOVELASCO, J.; LÓPEZ-ROMERO, G. Application of soil amendments and their effect in the growth of heliconia. Ornamental Horticulture, v.24, n.3, p.7, 2018. DOI: 10.14295/oh.v24i3.1252.

LINARES-GABRIEL， A.; LÓPEZ-COLLADO, C.J.; TINOCO-ALFARO, C.A.; VELASCO-VELASCO, J.; LÓPEZ-ROMERO, G. Application of biol, inorganic fertilizer and superabsorbent polymers in the growth of heliconia (Heliconia psittacorum cv. Tropica). Revista Chapingo. Serie horticultura, v.23, n.1, p.35-48, 2017 a. DOI: 10.5154/r.rchsh.2016.02.004.

LINARES-GABRIEL, A.; RODRÍGUEZ-OROZCO, N.; HERNÁNDEZ-CHONTAL, M.A. Effect of hydration in vase life of two Heliconia cultivars. Ornamental Horticulture, v.25, p.74-79, 2019. DOI: http://dx.doi. org/10.14295/oh.v25i1.1987.

LINARES-GABRIEL, A.; VELASCO-VELASCO, J.; RODRÍGUEZ-OROZCO, N.; TINOCO-ALFARO, C.; HERNÁNDEZ-CHONTAL， M.; LÓPEZ-COLLADO, C. Comercialización de heliconias (Heliconia L.) en Acayucan, Veracruz, México. Agroproductividad, v.10, n.3, p.56-61, $2017 \mathrm{~b}$. 
LOGES, V.; CASTRO, A.C.R.; COSTA, A.S.; VERONA, A.L.; NOGUEIRA, L.C.; GUIMARÃES, W.N.R.; CASTRO, M.F.A.; BEZERRA, M. The ornamental attributes of heliconia for landscape design in Brazil. Acta Horticulturae, p.75-80, 2007. DOI: 10.17660/ ActaHortic.2007.743.9.

LOGES, V.; DE CASTRO, C.E.F.; DE CASTRO, A.C.R.; GONÇALVES, C. Characteristics of pendent heliconia for use in landscape and as cut flower. Ornamental Horticulture v.22, n.3, p.287-295, 2016. DOI: 10.14295/ oh.v22i3.942.

LOGES, V.; TEXEIRA, M.C.F.; SILVA, S.S.L.; LAGO, P.G.P.; SILVA, S.A.C.G.; LIMA, T.L.D.; CASTRO, A.C.R. On farm Heliconia cut flower selection in Pernambuco â Brazil. Acta Horticulturae, v.1104, p.455-462, 2015. DOI: 10.17660/ActaHortic.2015.1104.65.

MALAKAR, M.; ACHARYYA, P.; BISWAS, S. Consequences of divergent vase solutions on postharvest durability and quality of Heliconia inflorescences. Acta Horticulturae, v.1256, p.77-94, 2019. DOI: 10.17660/ ActaHortic.2019.1256.12.

MEREDITH, J.R.; RATURI, A.; AMOAKO GYAMPAH, K.; KAPLAN, B. Alternative research paradigms in operations. Journal of Operations Management, v.8, n.4, p.297-326, 1989.

MERIDA, D.; CASTRO, C.E.F.; GONÇALVES, C.; PIMENTA, R.S.; TUCCI, M.L.S.; MOREIRA, S.R. Potential use of Heliconia Brazilian species as cut flower Acta Horticulturae, p.139-145, 2013. DOI: 10.17660/ ActaHortic.2013.1000.16.

MORAIS, M.B.; SILVA, M.M.A.; HERCULANO, L.; CAMARA, T.R.; WILLADINO, L. Postharvest senescence of alpinia floral stems: antioxidative effect of pulsing. Acta Horticulturae, v.1060, p.289-294, 2015. DOI: 10.17660/ ActaHortic.2015.1060.43.

NETO, A.D.S.M.; JANIE MENDES, J.; NIRALDO, J.P. Economia na produção de helicônias no Estado do Rio de Janeiro economy in helicônias production in Rio de Janeiro State. Ciência Rural, v.41, n.10, p.18581863, 2011. DOI: https://dialnet.unirioja.es/servlet/ articulo? codigo $=5672927$.

NIHAD, K.; BERWAL, M.K.; HEBBAR, K.B.; BHAT, R.; HARIS, A.A.; RAMESH, S. Photochemical and biochemical responses of heliconia (Heliconia stricta 'Iris') to different light intensities in a humid coastal environment. Horticulture, Environment, and Biotechnology, v.60, n.6, p.799-808, 2019. DOI: https://doi.org/10.1007/ s13580-019-00173-1.

NVIVO. NVIVO 11 for Windows: QSR International 2011
OLIVEIRA, M.; ATALLA, A.A.; FRIHLING, B.E.F.; CAVALHERI, P.S.; MIGLIOLO, L.; MAGALHÃES FILHO, F.J. Ibuprofen and caffeine removal in vertical flow and free-floating macrophyte constructed wetlands with Heliconia rostrata and Eichornia crassipes. Chemical Engineering Journal, v.373, p.458-467, 2019. DOI: https://doi.org/10.1016/j.cej.2019.05.064.

OLIVEIRA, T.R.S.; COSTA, E.K.S.L.; CÂMARA, C.A.G.; LOGES, V. Postharvest durability of Heliconia bihai flower stem treated with essential oils for insect control. Acta Horticulturae, v.1060, p.229-234, 2012. DOI: 10.17660/ActaHortic.2015.1060.34.

PATEL-CAMPILLO, A. Rival commodity chains: Agency and regulation in the US and Colombian cut flower agro-industries. Review of International Political Economy, v.17, n.1, p.75-102, 2010. DOI: 0.1080/09692290903296094.

PATEL-CAMPILLO, A.. Transforming Global Commodity Chains: Actor strategies, regulation, and competitive relations in the Dutch Cut Flower Sector. Economic Geography, v.87, n.1, p.79-99, 2011. DOI: 10.1111/j.19448287.2010.01102.x.

PAULINO, A.D.S.; ALBUQUERQUE, A.W.; MOURA FILHO, G.; PEREIRA, F.R.D.S. Helicônia "Golden Torch": produtividade e qualidade pós-colheita sob diferentes fontes e doses de silício. Revista brasileira de engenharia agrícola e ambiental, v.17, n.6, p.615-621, 2013. DOI: $10.1590 /$ S1415-43662013000600007.

PEÑA-SALAMANCA, E.J.; MADERA-PARRA, C.A.; SÁNCHEZ,J.M.; MEDINA-VÁSQUEZ,J.Bioprospección de plantas para su uso en procesos de biorremediación: caso Heliconia psittacorum (Heliconeacea) Revista de la Academia Colombiana de Ciencias Exactas, Físicas y Naturales, v.37, n.145, p.469-481, 2013. DOI: http://www. scielo.org.co/scielo.php?script $=$ sci_arttext\&pid=S0370$39082013000400004 \&$ lang $=$ pt.

PEREAÑEZ, J.A.; JIMÉNEZ, S.L.; QUINTANA, J.C.; NUÑEZ, V.; FERNÁNDEZ, M.; RESTREPO, Y. Inhibición de las actividades proteolítica, coagulante y hemolítica indirecta inducidas por el veneno de Bothrops asper por extractos etanólicos de tres especies de heliconias. Vitae, v.15, n.1, 2008.

PEREIRA, F.R.A.; MORAES, R.M.; MARTINS, L.S.S.; MONTARROYOS, A.V.V.; LOGES, V. Genetic diversity and morphological characterization of half-sib families of Heliconia bihai L., $H$. chartacea Lane ex Barreiros, and $H$. wagneriana Peterson. Genetics and Molecular Research, v.15, n.2, p.9, 2016. DOI http://dx.doi.org/10.4238/ gmr. 15028003 . 
PÉREZ-CÁRDENAS， N.; PORRAS-BRENES， K.; AUCCACUSI-CHOQUE, L.V.; SUÁREZ-TORRES, J.J.; BROOKS, R.M.; CHAVERRI, G. Microclimate of developing tubular leaves used as roost sites by bats. Acta Chiropterologica, v.21, n.1, p.175-181, 019. DOI: https:// doi.org/10.3161/15081109ACC2019.21.1.014.

PÉREZ-SALAZAR, R.;MORA-APARICIO, C.;ALFAROCHINCHILLA， C.; SASA-MARÍN， J.; SCHOLZ, C.; RODRÍGUEZ-CORRALES, J.Á. Biogardens as constructed wetlands in tropical climate: A case study in the Central Pacific Coast of Costa Rica. Science of the Total Environment, v.658, p.1023-1028, 2019. DOI: https://doi. org/10.1016/j.scitotenv.2018.12.259.

PIZANO, M. International market trends - tropical flowers. Acta Horticulturae, v.683, p.79-86, 2005. DOI: 10.17660/ ActaHortic.2005.683.6.

QUINAYA, D.; D'ALMEIDA, J. Possibility of exploring and applying wastes from Some ornamental plants (Elatior etlingera; Costus comosus; Heliconia bihai) as sources of natural cellulosic fibers. Journal of Natural Fibers, p.1-9, 2019. DOI: https://doi.org/10.1080/15440478.2019.15811 18.

RAIZER, M.; IRIARTE-MARTEL, J.; LOPES, M.; QUISEN, R. Effect of 6-benzylaminopurine and coconut water on shoot multiplication of Heliconia chartacea 'Sexy Pink’. Acta Horticulturae, v.1155, p.173-176, 2015. DOI: 10.17660/ActaHortic.2017.1155.24.

RAIZER, M.D.M.; QUISEN, R.C.; VALENTE, M.S.F.; LOPES, R.; LOPES, M.T.G. Morphological and stomatal characterization of Heliconia chartacea Var. sexy pink induced polyploidy. Bioscience Journal, v.35, n.1, 2019. https://doi.org/10.14393/BJ-v35n1a2019-41748.

ROCHA, F.H.A.; LOGES, V.; COSTA, A.S.D.; ARAGÃO, F.A.S.D.; SANTOS, V.F. Genetic study with Heliconia psittacorum and interspecific hybrids. Crop Breeding and Applied Biotechnology, v.10, n.4, p.282-288, 2010. DOI: http://dx.doi.org/10.1590/S1984-70332010000400001.

RODRIGUES, A.A.J.; SANTOS, E.O.; CARVALHO, A.C.P.P. Photoperiod and growth regulators on in vitro shoot induction in Heliconia latispatha. Ornamental Horticulture, v.22, n.3, p.343-349, 2016. DOI: https://doi. org/10.14295/oh.v22i3.932.

RODRÍGUEZ, F.M.S. Cultivo del género Heliconia. Cultivos Tropicales, v.34, n.1, p.24-32, 2013.

RODRÍGUEZ-HERRERA， B.; RODRÍGUEZ， P.; WATSON, W.; MCCRACKEN, G.F.; MEDELLÍN, R.A.; GALVÁN, I. Sexual dichromatism and conditiondependence in the skin of a bat. Journal of Mammalogy, v.100, n.2, p.299-307, 2019. DOI: https://doi.org/10.1093/ jmammal/gyz035.
ROY, S.; CHOUDHURY, P.; DHARA, M.; ADHIKARI, L. Smart alternative to cytotoxicity study and anti-angiogenic activity of different extracts of Heliconia rostrata. Research Journal of Pharmacy and Technology, v.12, n.12, p.61076110, 2019. DOI: 10.5958/0974-360X.2019.01061.8.

SANDOVAL, L.; ZAMORA-CASTRO, S.A.; VIDALÁLVAREZ, M.; MARÍN-MUÑIZ, J.L. Role of wetland plants and use of ornamental flowering plants in constructed wetlands for wastewater treatment: A review. Applied Sciences, v.9, n.4, p.685, 2019. DOI: https://doi. org/10.3390/app9040685.

SARANDÓN, S.J. Potencialidades, desafíos y limitaciones de la investigación agroecológica como un nuevo paradigma en las ciencias agrarias. Revista de la Facultad de Ciencias Agrarias, v.51, n.1, p.383-394, 2019.

SARDINHA, D.H.S.; RODRIGUES, A.A.C.; DINIZ, N.B.; LEMOS, R.N.S.D.; SILVA, G.S.D. Fungos e nematóides fitopatogênicos associados ao cultivo de flores tropicais em São Luís - MA. Summa Phytopathologica, v.38, p.159-162, 2012. http://dx.doi.org/10.1590/S010054052012000200010

SARDINHA, D.H.S.; RODRIGUES, A.A.C.; RIBEIRO, S.S.M.; DINIZ, N.B.; NETO, J.R.M.C.; REIS, F.O. Phytostimulants influence the vase life of Heliconia psittacorum cv. Golden Torch. Postharvest Biology and Technology, v.155, p.140-148, 2019. DOI: https://doi. org/10.1016/j.postharvbio.2019.05.001.

SHOKALU, A.; AKINTOYE, H.; OLATUNJI, M.; ADEBAYO, A.; JAMES, I. Use of organic and inorganic solutions for extending the vase life of cut Heliconia 'Golden Torch'flowers. Acta Horticulturae, v.1263, p.497-502, 2019. DOI: 10.17660/ActaHortic.2019.1263.64.

SILVA, C.G.D.; KRAUSE, S.; BOTINI, A.F.; FRANÇA, R.P.A.D.; SILVA, C.A. Postharvest durability of Heliconiaceae evaluated in a controlled environment in Mato Grosso state, Brazil. Ornamental Horticulture, v.25, n.1, p.80-86, 2019. DOI: ttps://doi.org/10.14295/ oh.v25i1.1229.

SOBRINHO, C.C.D.; DA SILVEIRA, A.J.; CESAR, F.B.D.; DE OLIVEIRA, C.M.G.; BITTENCOURT, M.A.L. Phytonematodes associated with Heliconia spp. in commercial crops in the South coast of Bahia, Brazil. Nematropica, v.42, n.2, p.351-355, 2012.

SOUZA, R.R.; CAVALCANTE, M.Z.B.; SILVA, E.M.; AMARAL, G.C.; BRITO, L.P.S.; AVELINO, R.C. Growth and changes on morphology and physiology of heliconias according to different shading environments. Comunicata Scientiae, v.7, n.2, p.214-222, 2016. DOI: https:// comunicatascientiae.com.br/comunicata/article/view/884/ www.cnpq.br. 
TEMELES, E.J.; BISHOP, G.A.A hurricane alters pollinator relationships and natural selection on an introduced island plant. Biotropica, v.51, n.2, p.129-138, 2019. DOI: https:// doi.org/10.1111/btp.12634.

TEMELES, E.J.; LIANG, J.; LEVY, M.C.; FAN, Y.-L. Floral isolation and pollination in two hummingbirdpollinated plants: the roles of exploitation barriers and pollinator competition. Evolutionary Ecology, v.33, n.4, p.481-497, 2019. DOI: https://doi.org/10.1007/s10682019-09992-1.

TLAHUEXTL-TLAXCALTECA, C.; ÁVILA-SANCHEZ, J.; LESZCZYÑSKA-BORYS, H. Flores de corte y follaje en florerías y mercados de Puebla, México. Revista Chapingo Serie Horticultura, v.11, n.2, 2005.

TOKARZ, E.L.; ÁlVIA, P.; VALENCIA, R.; QUEENBOROUGH, S.A. Habitat filtering of six coexisting Heliconia species in a lowland tropical rain forest in Amazonian Ecuador. Journal of Tropical Ecology, v.35, n.2, p.91-94, 2019. DOI: https://doi.org/10.1017/ S0266467419000026.
TORRES-VANEGAS, F.; HADLEY, A.S.; KORMANN, U.G.; JONES, F.A.; BETTS, M.G.; WAGNER, H.H. The landscape genetic signature of pollination by trapliners: Evidence from the tropical herb, Heliconia tortuosa. Frontiers in Genetics, v.10, p.1206, 2019. DOI: https:// doi.org/10.3389/fgene.2019.01206.

VÁZQUEZ-EUÁN, R.; CHI-MANZANERO, B.; HERNÁNDEZ-VELÁZQUEZ， I.; TZEC-SIMÁ, M.; ISLAS-FLORES, I.; MARTÍNEZ-BOLAÑOS, L.; GARRIDO-RAMÍREZ, E.R.; CANTO-CANCHÉ, B. Identification of new hosts of pseudocercospora fijiensis suggests innovative pest management programs for black sigatoka disease in banana plantations. Agronomy, v.9, n.10, p.666, 2019. DOI: https://doi.org/10.3390/ agronomy9100666.

VERBEKE, W.; MARCU, A.; RUTSAERT, P.; GASPAR, R.; SEIBT, B.; FLETCHER, D.; BARNETT, J. 'Would you eat cultured meat?': Consumers' reactions and attitude formation in Belgium, Portugal and the United Kingdom. Meat science, v.102, p.49-58, 2015. DOI: https://doi. org/10.1016/j.meatsci.2014.11.013. 